\title{
Environmental forcing on phytoplankton biomass and primary productivity of the coastal ecosystem in Ubatuba region, southern Brazil
}

\author{
Salvador Airton Gaeta ${ }^{1,2}$, Sylvia Maria Susini Ribeiro ${ }^{1}$, \\ Patricia Mercedes Metzler ${ }^{2}$, Maria Solange Francos \& Donato Seiji $\mathrm{Abe}^{3}$ \\ ${ }^{1}$ Instituto Oceanográfico da Universidade de São Paulo \\ (Caixa Postal 66149, 05315-970 São Paulo, SP, Brasil) \\ ${ }^{2}$ Fundação de Estudos e Pesquisas Aquáticas - FUNDESPA \\ (Av. Caxingui, 160, 05579-000 São Paulo, SP, Brasil) \\ ${ }^{3}$ Instituto Internacional de Ecologia - IIE \\ (Caixa Postal 694, 13560-460 São Carlos, SP, Brasil)
}

- Abstract: A time series of chlorophyll $a$ and in situ primary production sampled over a period of 33 days during summer in Ubatuba region, southeastern Brazil, was subjected to multivariate and harmonic analysis. Principal Component Analysis has revealed four factors interpreted as (i) South Atlantic Central Water forcing; (ii) Transient frontal systems and rain fall forcings; (iii) Wind forcing normal to the coast; (iv) Wind forcing parallel to the coast, as main factors in the variability of the phytoplankton biomass and primary productivity. Splitting of the time series according to four main events which had profound effects on the physicochemical characteristics of the region showed the following variations in the primary productivity integrated over the photic layer $\left(\mathrm{g} \mathrm{C} \mathrm{m}^{-2} \mathrm{day}^{-1}\right)$ : mixing $\rightarrow$ stratification period, $0.40 \pm 0.11$; heavy rainfall, $1.24 \pm 0.28$; stratification after rainfall, $0.74 \pm 0.10$; stratification $\rightarrow$ mixing period, $0.90 \pm 0.27$; stratification after deep mixing, $0.63 \pm 0.28$. Harmonic analysis revealed two indistinguishable significant peaks of the phytoplankton biomass - one at a period of 8.25 days and one at a period of 6.6 days, contributing, respectively, about 17 and $32 \%$ of the total variance. Atmospheric forcing showed a characteristic period of 200-264 hours while phytoplankton biomass response ranged over the 144-192 hours time scales and primary productivity was best related to the environment 360 hours before. Relative to total nitrogen and biomass primary productivity oscillations were lagged about 96-144 hours. The interruption of steady-state conditions by transient atmospheric events and wind field intensification are the determining factors driving phytoplankton changes in this coastal environment.

- Resumo: Uma série temporal de clorofila $a$ e produção primária obtida em um período de 33 dias durante o verão na região de Ubatuba, sudeste do Brasil, foi submetida à análise multivariada e harmônica. A Análise de Componentes Principais revelou quatro fatores interpretados como (i) Água Central do Atlântico Sul; (ii) Sistemas frontais transientes e chuvas; (iii) Ventos normais à costa; (iv) Ventos paralelos à costa. Estes fatores atuam como forçantes ambientais na determinação da variabilidade observada na biomassa fitoplanctônica e produtividade primária. A divisão da série temporal de acordo com quatro eventos modificadores das características físicoquímicas da região mostrou a seguinte variabilidade na produção primária integrada ( $\left.\mathrm{g} \mathrm{C} \mathrm{m}^{-2} \mathrm{dia}^{-1}\right)$ na camada eufótica: coluna de água homogênea em processo de estratificação térmica- $0,40 \pm 0,11$; coluna de água estratificada e chuvas intensas- $1,24 \pm 0,28$; coluna de água misturada em fase de estratificação térmica após intensas chuvas- $0,74 \pm 0,10$; coluna de água estratificada em fase de processo de mistura- $0,90 \pm 0,27$; coluna de água homogênea em fase de estratificação térmica após intensa mistura- $0,63 \pm 0,28$. A Análise Harmônica revelou dois picos de biomassa significativos- um com período de 8,25 dias e outro com período de 6,6 dias, contribuindo, respectivamente, com 17 e $32 \%$ da variância total da série. A forçante atmosférica apresentou um período característico de 200-264 horas enquanto que a escala de resposta da biomassa fitoplanctônica variou de 144-192 horas e a de produtividade primária um período de 360 horas. Em relação à biomassa e nitrogênio total, a produtividade primária apresentou uma defasagem de $96-144$ horas.

- Descriptors: Chlorophyll $a$, Primary productivity, Time series, Ubatuba coastal waters.

- Descritores: Clorofila $a$, Produtividade primária, Séries temporais, Águas costeiras de Ubatuba. 


\section{Introduction}

According to Margalef (1978), the input of external turbulent energy in the water column acts as the supplementary energy to the plankton communities. This is the case in shallow and frequently disturbed systems where wind is the main source of kinetic energy generating water exchanges between the shelf and the coast (Castro Filho et al., 1987).

The Ubatuba region on the northern coast of São Paulo State-Brazil has been studied with relation to the phytoplankton and the primary production specially in coastal stations (Kutner, 1961; Tundisi et al., 1978; Sassi, 1978; Kutner \& Sassi, 1979; Sassi \& Kutner, 1982; Oliveira, 1980; Teixeira \& Tundisi, 1981; Teixeira, 1973; 1979; 1980; Perazza, 1982; Teixeira \& Gaeta, 1990; Gaeta et al., 1990); and in the shelf by Soares (1983) and Susini-Zilmann (1990). Available data on environmental forcing in this region is restricted to surface sampling at a fixed station inside the Flamengo Bay, a well protected environment under the peculiar hydrodynamic mechanisms of very shallow waters (Teixeira, 1986). We hypothesize that wind and other environmental forces are significant factors in phytoplankton productivity and biomass accumulation in this region.

In summer 1988, we followed phytoplankton and in situ primary production dynamics in the coastal inshore waters of Ubatuba region. The time series of Chlorophyll $a$, Primary Production and associated environmental variables are presented. The results of multivariate and harmonic analysis of these series are discussed.

\section{Materials and methods}

The sampling station was located in the coastal zone at Boqueirão near Anchieta Island on the north coast of the São Paulo State, Brazil (Fig. 1). This sampling station was occupied for 33 consecutive days, between 12 February and 15 March 1988. Water samples were collected with $5 \mathrm{~L}$ Van Dorn bottles at five depths corresponding to the light extinction percentages of $100,50,25,10$ and $1 \%$, obtained with the Secchi disc, at 6:00, 12:00 and 18:00 h (local time).

Primary production was determined in situ with subsamples collected at 6:00 and 12:00 $\mathrm{h}$ and kept horizontally in the water column at the original depths. A system of stainless steel frames attached to the hydrographic wire with a weight of $7 \mathrm{~kg}$ and a buoy was tied to the boat at a distance long enough to prevent shading. The subsamples $(60-85 \mathrm{ml})$ were incubated from 4 to $6 \mathrm{~h}$ with two transparent bottles and one dark bottle with $10 \mu \mathrm{Ci} \mathrm{Na} \mathrm{H}^{14} \mathrm{CO}_{3}$ (IEAPM) twice a day (08:00-12:00 and 12:00-16:00). The particulate Carbon was retained in $25 \mathrm{~mm}$ Millipore HA filters with $0.45 \mu \mathrm{m}$ nominal pore size and kept in Silica gel. In the laboratory, the ${ }^{14} \mathrm{C}$ treated filters were exposed to fuming $\mathrm{HCl}$ for 10-15 min to remove traces of inorganic ${ }^{14} \mathrm{C}$ prior to counting. Dark fixation values in relation to ${ }^{14} \mathrm{C}$ assimilation in the light bottles ranged from 5 to $15 \%$. The DPM number was measured by liquid scintillation (Packard Tri-Carb 1600CA) using the internal standard quenching curves. The primary production was calculated according to each incubation period and extrapolated for half light period (morning and afternoon) using the recordings from the meteorological station of the IOUSP North Station, located about $5 \mathrm{~km}$ from our sampling site. The daily values were obtained by the sum of the two integrated values in the water column and are expressed in $\mathrm{mg} \mathrm{C} \mathrm{m}^{-2} \mathrm{~d}^{-1}$.

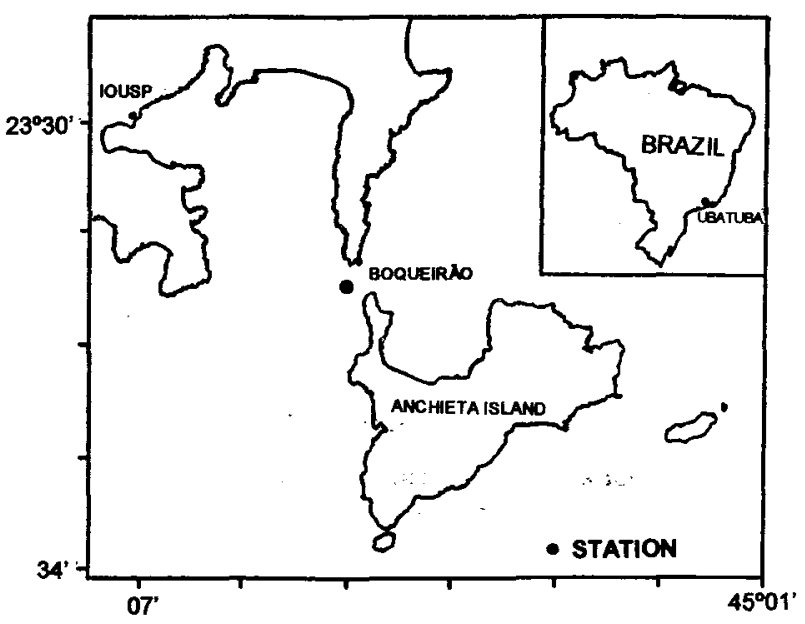

Fig. 1. Map showing the location of the sampling station.

The phytoplankton biomass was retained in Whatman GF/F filters and estimated by Chlorophyll $a\left(\mathrm{mg} \mathrm{Chl} a \mathrm{~m}^{-3}\right)$ after extraction in $90 \%$ acetone using the trichromatic equations of Jeffrey \& Humphrey (1975); and pheopigments using Lorenzen and Jeffrey (1980). The nutrients were determinated following Grasshoff et al., $1983\left(\mathrm{NO}_{3}{ }^{-}\right.$, $\mathrm{NO}_{2}{ }^{-}, \quad \mathrm{PO}_{4}{ }^{\equiv}$ and $\left.\mathrm{Si}(\mathrm{OH})_{4}\right)$ and Aminot \& Chaussepied, $1983\left(\mathrm{NH}_{4}^{+}\right)$in the filtered sea water. All results of nutrients and pigments were integrated from the top to the bottom of the photic zone and are expressed in $\mathrm{mmol} \mathrm{m}$ and $\mathrm{mg} \mathrm{m}^{-2}$, respectively. 
The temperature was measured with reversible thermometers using Nansen bottles at fixed depths $(0,5,10,20$ and $30 \mathrm{~m})$ and corrected with their own calibration curves. The salinity was measured with an induction salinometer (Beckman RS-7C) after frequent calibration with normal water and using the Practical Salinity Scale of UNESCO (1981a).

The sea water density $\left(\sigma_{t}\right)$ was calculated by the International State Equation (UNESCO, 1981b). Estimation of the differences in the vertical gradients of in situ density was obtained by means of graphic interpolation, taking into account the recommendations of Millard et al. (1990). The mixed layer extended from surface until the depth at which the vertical gradient of density started continuously. The water column stability was estimated through $\Delta \mathrm{T}$ (temperature difference between surface, $\mathrm{z}_{0}$, and bottom of the euphotic zone, $\left.\mathrm{z}_{\mathrm{e}}\right)$ and $\Delta \sigma_{\mathrm{t}}\left(\sigma_{\mathrm{t}} \mathrm{z}_{0}-\sigma_{\mathrm{t}} \mathrm{z}_{\mathrm{e}}\right)$. Also the euphotic zone : mixing layer ratio $\left(\mathrm{z}_{\mathrm{e}}: \mathrm{z}_{\mathrm{m}}\right)$ was estimated.

The meteorological data of global solar radiation $\left(\mathrm{Cal} \mathrm{cm} \mathrm{cm}^{-2} \mathrm{~h}^{-1}\right)$ and rain fall $(\mathrm{mm})$, measured at the Ubatuba Station were collected by the IOUSP Physical Oceanography Department -Meteorology Laboratory and expressed as $\mathrm{W} \mathrm{m}^{-2} 6 \mathrm{~h}^{-1}(1 / 2$ photoperiod, morning and afternoon) and $\mathrm{mm} 12 \mathrm{~h}^{-1}$ before sampling. Wind speed and direction, registered at the Moela Island $\left(24^{\circ} 03^{\prime} \mathrm{S} 46^{\circ} 16^{\prime} \mathrm{W}\right)$ were obtained from DHN-Brazilian Navy and expressed as degrees and $\mathrm{m} \mathrm{s}^{-1}$, respectively.

The data were reduced to a rectangular matrix of environmental parameter values versus sampling periods. For Principal Component Analysis (PCA) analysis a matrix of product-moment correlation coefficients was calculated from the standardized data (Draper \& Smith, 1966; Legendre \& Legendre, 1984a; 1984b) and the first four eigenvectors were extracted along with the corresponding eigenvalues for each plot.

All time series were expressed in a common sample period of 12 hours. The time series were subjected to Harmonic Analysis (Jenkins \& Watts, 1968). This statistical operation may be regarded as an analysis of variance in which the total variance of a variable or property fluctuation is partitioned into contributions arising from processes with different characteristic time scales (Platt \& Denman, 1975). Thus, harmonic analysis of a record of observations results in a sorting of total variance of the record into its component frequencies. The harmonic results presented in this paper were computed with a fast Fourier transform algorithm. The number of sampling observations was 66 with a sampling interval of $12 \mathrm{~h}$ ( 33 harmonics). Critical values of the periodograms were estimated as by Anderson (1971).

\section{Results}

Chlorophyll $a$, total dissolved inorganic nitrogen, pheopigments and primary production: distribution and variability.

Chlorophyll $a$ distribution (Fig. 2A) was shifted for values up to $10.0 \mathrm{mg} \mathrm{m}^{-2}$, showing the average value of 16.2 , standard deviation of 11.2 and error (estimated by the quotient between the confidence interval for $90 \%$ and two times the parametric average) of $114 \%$. Practically $70 \%$ of the observations were between 1.5 and 20.0 and the highest value $\left(53.3 \mathrm{mg} \mathrm{m}^{-2}\right)$ occurred at Mar. $6^{\text {th }}$ (Fig. 3J) after a 6 day period of prevailing winds (Figs $3 \mathrm{~A}$ and $3 \mathrm{~B}$ ) that favored the turbulence and mixing processes (Figs $3 \mathrm{D}$ and $3 \mathrm{E}$ ). Three other peaks can be seen in Fig. 3J: between Feb. 18th and $19^{\text {th }}$, Feb. $28^{\text {th }}$ and $29^{\text {th }}$ and at Mar. $15^{\text {th }}$. The last two occurred at the thermal stratification period (Fig. 3D, Feb. $23^{\text {rd }}$ to $28^{\text {th }}$ and Mar. $10^{\text {th }}$ to $15^{\text {th }}$ ) with the presence and evolution of a pycnocline (Fig. 3E, Feb. $23^{\text {rd }}$ to $27^{\text {th }}$ and Mar. $10^{\text {th }}$ to $15^{\text {th }}$, respectively). At these two periods, the prevailing winds were from the first quadrant (Fig. 3B) and the intensities were from 2 to $7 \mathrm{~m} \mathrm{~s}^{-1}$ (Fig. 3A). The first peak of the series occurred between Feb. $18^{\text {th }}$-and $19^{\text {th }}$ and can be associated to a progressive stratification process period (Fig. 3D and 3E, Feb $12^{\text {th }}$ to $19^{\text {th }}$ ). At this period one can see the prevailing winds, at low to moderate strength (Fig. 3B), from the first quadrant (Fig. 3A) before the chlorophyll $a$ peak.

Total dissolved inorganic nitrogen (Fig. 2B) showed an average value of $28.3 \mathrm{mM} \mathrm{N} \mathrm{m}^{-2}$, s.d. 16.0 and a range from 9.6 to 75.3 . About $85 \%$ of the observations fell between 9.6 and $37.9 \mathrm{mM} \mathrm{N} \mathrm{m}^{-2}$. In general, nitrogen changes (Fig. 3H) roughly followed those observed in $\Delta T$ (Fig. 3D). Data suggest a relationship between thermal stratification processes and nitrogen with coinciding peaks; the exceptions were at Mar. $4^{\text {th }}, 6^{\text {th }}, 7^{\text {th }}$ and $11^{\text {th }}$, which could be associated to turbulence and rainfall periods.

Pheopigments (Fig. 2C) showed $71 \%$ of the values between 0.5 and $22.0 \mathrm{mg} \mathrm{m}^{-2}$, with an average of 17.1 , s.d. 15.5 and an error of $151 \%$. In the time series (Fig. 3K), the first two peaks between Feb. $17^{\text {th }}$ and $18^{\text {th }}$ and Feb. $19^{\text {th }}$ to $20^{\text {th }}$ appeared to be related to the modifying events of the water column (Fig. 3D and $3 \mathrm{E}$ ) and to the nitrogen availability (Fig. $3 \mathrm{H}$ ), the latter with continental run off contribution (Fig. $3 C$ ). Between Feb. $29^{\text {th }}$ and Mar. $3^{\text {rd }}$, three successive pheopigment peaks, with an extensive 
chlorophyll $a$ trough at the same time, suggest to indicate active grazing process. It is worth noting the wind direction change ( $3^{\text {rd }}$ and $4^{\text {th }}$ quadrant; Fig. 3A) and the water column mixing (Fig. 3D and 3E).

Primary production (Fig. 2D) showed an average value (mg C m$~^{-2} 6 \mathrm{~h}^{-1}$ ) 352.4, s.d. 202.0 and the error $100 \%$. About $71 \%$ of the observations were between 80.3 and 355.3 and one observation was higher than 1,000 three days after a rain fall peak (Fig. 3C).

\section{Multivariate analysis}

Table 1 shows the variables and the respective abbreviations for the PCA and the significance levels of the factor loadings (correlations between the variables and the principal components). Results showed four components explaining, respectively, $26,14,11$ and $10 \%$ of the total variance of the data. Figure $4 \mathrm{~A}$ shows the first two components. The first component is composed by the nutrients (TOTN $0.38^{* * *}$; NATE $0.34^{* * *}$; NITE $0.34^{* * *}$; PHOS $0.28^{* *}$ ), the ratio euphotic zone: mixing layer (ZEZM $0.32^{* * *}$ ) and the thermal gradient $\left(\Delta \mathrm{T} \quad 0.31^{* *}\right)$. The second component, explaining $14 \%$ of variance, is composed by rain fall (RAIN $0.40^{* * *}$ ), pheopigments (PHEO $0.35^{* * *}$ and Silicate (SILI $0.32^{* * *}$ ) opposing the phytoplankton biomass (CHLO $-0.30^{* * *}$ ), the total solar irradiation (IRRA $-0.27^{* *}$ ) and the light availability in the mixing zone (ZEZM $-0.22^{*}$ ).

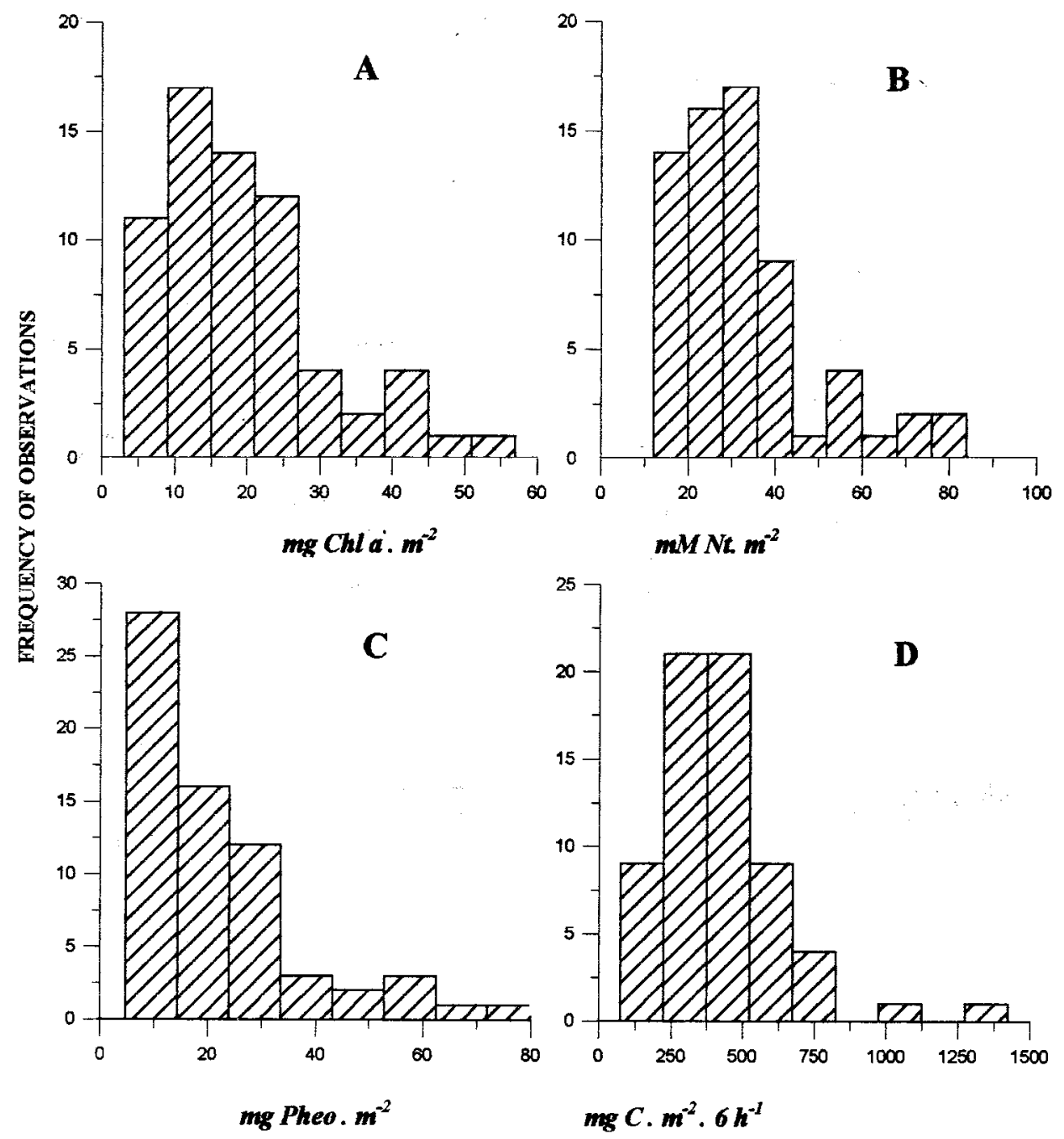

Fig. 2. Frequency distributions ( $\mathrm{n}=66$ ): (A) Chlorophyll $a$; (B) Total inorganic dissolved nitrogen; (C) Pheopigments; (D) Primary production. 


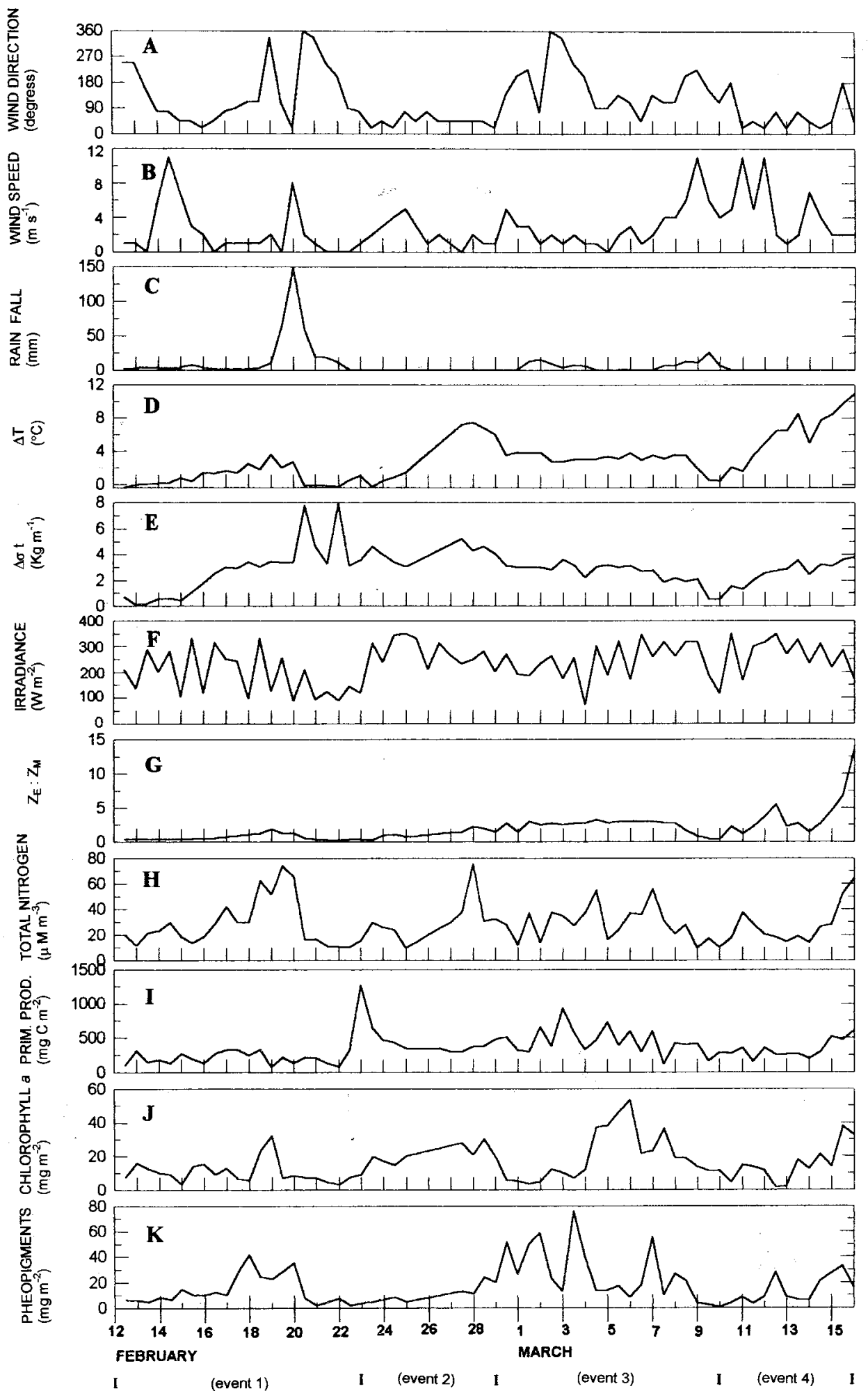

Fig. 3. Time series of physical, chemical and biological variables. 
Table 1. Principal component analysis: variables and factor loadings.

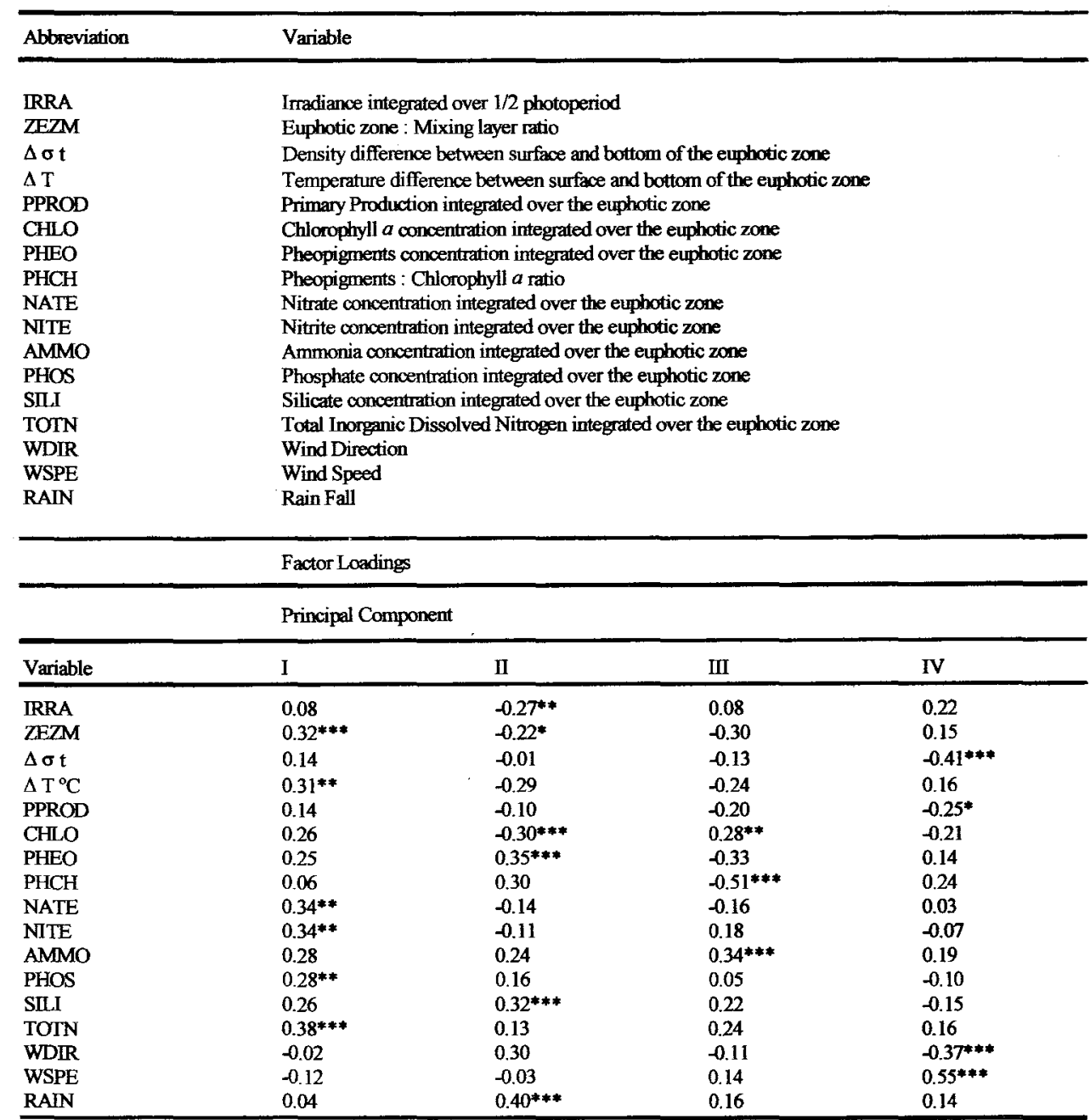

Levels of significance: *** $p<0.001, * * p<0.01, * p<0.05$
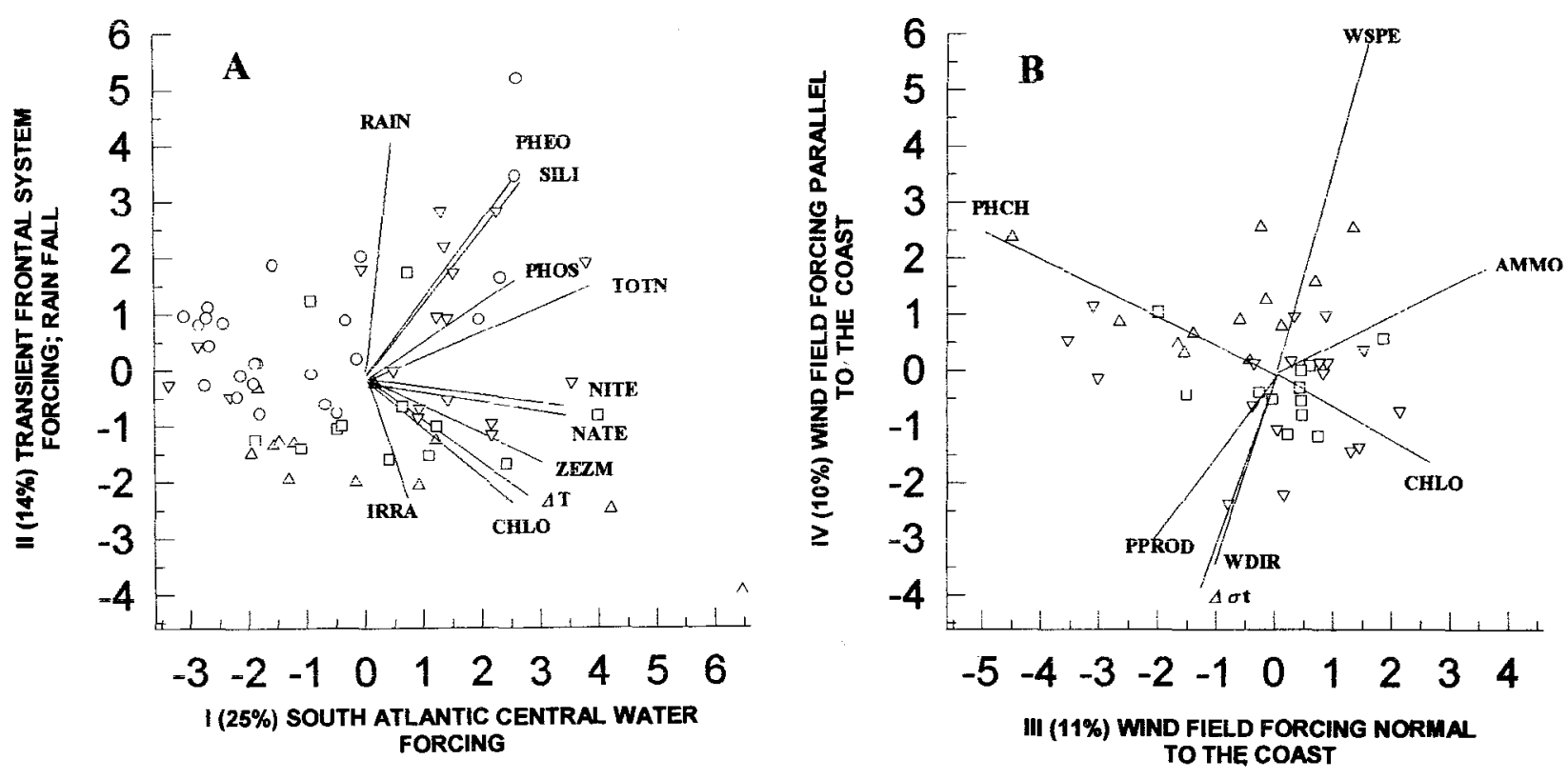

Fig. 4. Principal component analysis: (A) First x Second component; (B) Third $x$ Fourth component. (o Period 1- Feb. 12-23; $\square$ Period 2- Feb. 24-29; $\nabla$ Period 3 Mar. 01-09; $\Delta$ Period 4 Mar. 10-15). 
Figure 4B presents the third and fourth components. The third component, explaining $11 \%$ of variance, showed the variables ammonia and phytoplankton biomass (AMMO 0.34***; CHLO $0.28^{* *}$ ) opposing the ratio pheopigments: chlorophyll- $a$ (PHCH $\left.-0.51^{* * *}\right)$. The fourth component $(10 \%$ of variance) presented the variable wind speed (WSPE $0.55^{* * *}$ ) opposing the stability parameter $\left(\Delta \sigma-\mathrm{t}-0.41^{* * *}\right)$, to the wind direction (WDIR $-0.37^{* * *}$ ) and to the primary production (PPROD - $0.25^{*}$ ).

According to the data, four main events during the sampling period have been observed (Table 2). These four events presented effects not only on the physico-chemical characteristics of the water mass, but also on the phytoplankton biomass and primary production: the daily integrated primary production in the euphotic zone $\left(\mathrm{g} \mathrm{C} \mathrm{d}^{-1}\right)$, showed the following results: $0.40 \pm 0.11$ (amplitude of variation from 0.21 to 0.59 ) at the mixing $\rightarrow$ stratification period; $1.24 \pm 0.28$ (a.v. 0.63 to 0.86 ) during and just after heavy rain fall; $0.74 \pm 0.10$ (a.v. 0.63 to 0.86 ) at stratification period after rain fall; $0.90 \pm 0.27$ (a.v. 0.45 to 1.2 ) at stratification $\rightarrow$ mixing period; and $0.63 \pm 0.28$ (a.v. 0.26 to 1.07 ) at stratification period after strong mixing.

Taking into account these four main events (Fig. 3) we divided the time series in four periods, in order to discriminate the most significant covariables that explain the biomass and production variance, and at the same time, to compare which of them acted as main forcings at the respective periods. Results for regression and multiple correlations analysis are presented in Tables 3 and 4.
Phytoplankton biomass changes during the total time series (Table 3, regression I) showed that a total of $40 \%$ of the variability could be explained by four variables. The most important of them, contributing $26 \%$ of the variability was nitrite concentration, followed by silicate and nitrate concentrations each contributing $5 \%$ of the variability and rain fall contributing $4 \%$. The results obtained by this multilinear analysis model detach the direct influence of the forcing nutrients as the most significant and, in a second level, the inverse influence of the rain fall (see Table III, Equation for regression 1). Considering the total time series, results confirm the structure for the first component derived from the PCA (Fig. 4A).

For period 1 (Table 3, regression 2), a total of $44 \%$ of the biomass variability is accounted for by rain fall. It is concluded that for this period interference of the second principal component occurred.

For period 2 (Table 3, regression 3), a total of $89 \%$ of explanation of the biomass variability is accounted for by four variables, the contributions of which clearly suggest the interference of the first and fourth principal components. One variable, $\Delta \sigma \mathrm{t}$, explained $67 \%$ of the variability. One can note during this period (Feb. $24^{\text {th }}$ to $29^{\text {th }}$ ) the evolution and peak of total nitrogen, coinciding with increasing variations and peaks of the stability parameters $\Delta \mathrm{T}$ and $\Delta \sigma \mathrm{t}$ (Figs $3 \mathrm{H}, 3 \mathrm{D}$ and $3 \mathrm{E}$ ), preceded by increases of first quadrant wind speed (Figs $3 \mathrm{~A}$ and 3B).

Table 2. Meteorological, hydrographic, chemical and biological characteristics of four events during time series.

\begin{tabular}{|c|c|}
\hline Event & Characteristics \\
\hline $\begin{array}{c}1 \\
\text { (o Feb. 12-23) }\end{array}$ & $\begin{array}{l}\text { Variable southwesterly and easterly winds; high rain fall, salinity decrease, water } \\
\text { stability changes; total nitrogen increase; low phytoplankton biomass variations. }\end{array}$ \\
\hline $\begin{array}{l}2 \\
\text { (प Feb. 24-29) }\end{array}$ & $\begin{array}{l}\text { Northeasterly winds; thermal and haline stratification; total nitrogen and phyto- } \\
\text { plankton biomass increases. }\end{array}$ \\
\hline$\stackrel{3}{(\nabla \operatorname{Mar} .01-10)}$ & $\begin{array}{l}\text { Wind direction highly variable; progressive mixing increase; high oscilations in } \\
\text { total nitrogen and pheopigments; significant peaks in chlorophyll } a \text {. }\end{array}$ \\
\hline$\stackrel{4}{(\Delta \operatorname{Mar} .11-15)}$ & $\begin{array}{l}\text { Strong increases in northeasterly wind speed; thermal stratification; thermocline } \\
\text { ranging from } 5-17 \mathrm{~m} \text { to } 2-4 \mathrm{~m} \text {; nitracline at } 4 \mathrm{~m} \text { depth; euphotic zone : mixing depth } \\
\text { ratio, chlorophyll } a \text { and primary production increases. }\end{array}$ \\
\hline
\end{tabular}


Table 3. Stepwise regression for Chlorophyll $a$ (dependent) and significant covariables. D.F.- degrees of freedom; R- multiple correlation coefficient; $R^{2}$ - multiple determination coefficient; V- proportion (\%) of variance accounted for by each variable.

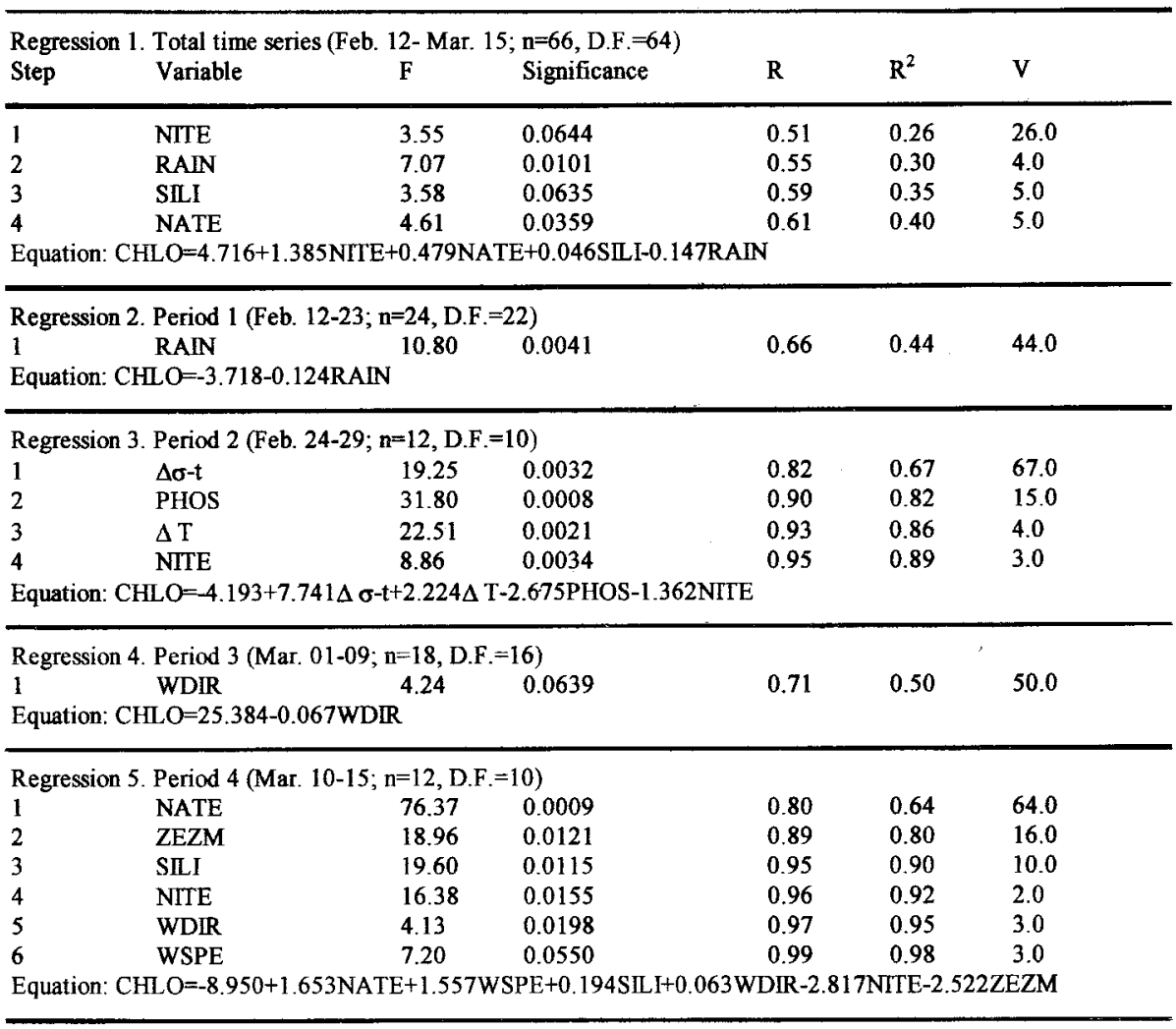

Table 4. Stepwise regression for Primary Production (dependent) and significant covariables. D.F.- degrees of freedom; R- multiple correlation coefficient; $\mathrm{R}^{2}$ multiple determination coefficient; $\mathrm{V}$ - proportion $(\%)$ of variance accounted for by each variable.

\begin{tabular}{|c|c|c|c|c|c|c|}
\hline \multicolumn{7}{|c|}{ Regresion 1. Total time series (Feb. $12-$ Mar. $15 ; n=66$. D.F $=64$ ) } \\
\hline Step & Variable & $\mathrm{F}$ & Significance & $\mathrm{R}$ & $\mathrm{R}^{2}$ & $\mathrm{~V}$ \\
\hline 1 & PHOS & 5.64 & 0.0299 & 0.28 & 0.08 & 8.0 \\
\hline 2 & RAIN & 4.76 & 0.0206 & 0.38 & 0.15 & 7.0 \\
\hline 3 & $\Delta \sigma-t$ & 3.25 & 0.0636 & 0.43 & 0.19 & 4.0 \\
\hline \multicolumn{7}{|c|}{ Equation: PPROD=176.51+16.37PHOS+31.27 $\Delta \sigma-t-2.70 \mathrm{RAIN}$} \\
\hline \multicolumn{7}{|c|}{ Regression 2: Period 1 (Feb. 12-23; n=24, D.F. $=22$ ) } \\
\hline 1 & WDIR & 1.69 & 0.0158 & 0.27 & 0.07 & 7.0 \\
\hline 2 & NATE & 1.54 & 0.0157 & 0.59 & 0.35 & 28.0 \\
\hline \multicolumn{7}{|c|}{ Equation: PPROD=863.85+35.84NATE-1.46WDIR } \\
\hline \multicolumn{7}{|c|}{ Regression 3: Period 2 (Feb. 24-29; n=12, D.F.=10) } \\
\hline 1 & WDIR & 30.23 & 0.0006 & 0.41 & 0.17 & 17.0 \\
\hline 2 & PHOS & 33.92 & 0.0004 & 0.73 & 0.53 & 36.0 \\
\hline 3 & $\Delta \mathrm{T}$ & 81.77 & 0.0000 & 0.85 & 0.73 & 20.0 \\
\hline 4 & AMMO & 11.79 & 0.0089 & 0.94 & 0.89 & 16.0 \\
\hline 5 & NATE & 6.91 & 0.0089 & 0.97 & 0.94 & 5.0 \\
\hline \multicolumn{7}{|c|}{ Equation: PPROD=366.56+1.23PHOS+0.53AMMO-1.04WDIR-1.28 $\Delta$ T-0.18NATE } \\
\hline \multicolumn{7}{|c|}{ Regression 4: Period 3 (Ma. 01-10, n=18, D.F.=16) } \\
\hline 1 & $\Delta \sigma-\mathbf{t}$ & 43.14 & 0.0001 & 0.77 & 0.59 & 59.0 \\
\hline 2 & $\overline{Z Z Z M}$ & 12.40 & 0.0065 & 0.87 & 0.76 & 17.0 \\
\hline 3 & $\Delta \mathrm{T}$ & 4.02 & 0.0759 & 0.92 & 0.86 & 10.0 \\
\hline \multicolumn{7}{|c|}{ Equation: PPROD $=194.66+316.25 \Delta \sigma-\mathrm{t}+99.00 \Delta \mathrm{T}-294.82 Z \mathrm{ZZZM}$} \\
\hline \multicolumn{7}{|c|}{ Regression 5: Period 4 (Mar. 11-15, n=12, D.F.=10) } \\
\hline 1 & PHOS & 9.63 & 0.0146 & 0.81 & 0.66 & 66.0 \\
\hline \multicolumn{7}{|c|}{ Equation: PPROD $=62.29+60.81 \mathrm{PHOS}$} \\
\hline
\end{tabular}


For period 3 (Table 3, regression 4) a total of $50 \%$ of variance is accounted for by wind direction. However it is inversely correlated with the biomass, apparently because the latter has shown a very lagged peak in relation to the wind field peak (Figs. 3A and $3 \mathrm{~J}$ ), mainly from the second quadrant. Thus, there was also influence of the fourth component.

For period 4 (Table 3, regression 5), a total of $98 \%$ of variance is accounted for by seven variables that characterize, as in period 2 , the interference of the first and fourth principal components. Nitrate concentration and euphotic zone: mixing layer ratio explained $80 \%$ of the biomass variability in this case.

When the results of the multiple regression analysis for the primary production are considered for the total time series (Table 4, regression 1), one can verify that $19 \%$ of variance is explained by three variables. Of those, only rain fall is common to the conjunct of variables which explains the biomass variability. Thus, primary production seemed to be influenced by the first and fourth principal components, nevertheless with relatively low contributions.

For period 1 (Table 4, regression 2), primary production variance was directly linked to nitrate $(28 \%)$ and inversely to wind direction $(8 \%)$ therefore under the influence of the first and fourth principal components.

For period 2 (Table 4, regression 3), 94\% of primary production variance is accounted for by phosphate and ammonia directly (36 and 16\%, respr-iively), and wind direction (17\%), thermal gradient $(20 \%)$ and nitrate $(5 \%)$ inversely. One may conclude that for this period the first, third, and fourth principal components determined the phytoplankton production variability.

For period 3 (Table 4, regression 4), there was also an excellent fitting with $86 \%$ of explanation being related to density gradient $(59 \%)$, light availiability in the the mixing layer $(17 \%)$ and thermal gradient $(10 \%)$. These variables, as stated before, are associated to the first and fourth principal components.

Finally, for period 4 (Table 4, regression 5), $66 \%$ of variance is accounted for by phosphate also characterizing the interference of the first principal wimponent.

\section{Harmonic analysis}

Harmonic analysis revealed a low frequency periodicity in the chlorophyll $a$ (period 8.25 days) that could be related to the periodicities of the stability parameter $\Delta \mathrm{T}$ and total nitrogen (Fig. 5), which showed two distinct significant peaks, one at a period of 6.6 days and one at a period of 4 days. Although no significant peak was observed in the wind direction and speed, data suggest a relationship, at low frequency, between atmospheric forcing and water column stratification, nitrogen availability and phytoplankton biomass changes. A second low frequency periodicity in the chlorophyll $a$ (6.6 days) appears to be accounted for by $\Delta T$.

The variations in the stability parameter $\Delta \sigma t$ at 11 day period also appear to be largely controlled by the wind field. At the 11 day period the responses of nitrate, phosphate and silicate were in phase with the water column density structure.

\section{Discussion}

Studies on horizontal diffusion using dyes led to well-defined relationships between the temporal and spatial scales of mixing processes (Boyce, 1974). From these relationships Harris (1980) defined the temporal and spatial scales that link the time and space dimensions in the planktonic system. Thus, for the sampling scheme of the present work, a little more than one month corresponds in horizontal and vertical spatial scale to dimensions of 1 to $50-80 \mathrm{~km}$ and of 0.5 to $50 \mathrm{~m}$, respectively. These scales, in view of the temporal and spatial description of the phytoplankton system, are consistent with the turbulent vertical diffusion coefficient values and with the time scales of the mixing processes available in literature. The sedimenting rates are commonly in order of $0.5 \mathrm{~m} \mathrm{~d}^{-1}$ (Smayda, 1970) and the dispersion of the observed sinking rates correlates well with the amplitude of variation of the vertical mixing rates calculated by Denmann \& Gargett (1983).

Component I, derived from PCA, was interpreted as the availability of new nutrients injected by continental shelf colder waters, during the pycnocline settlement, controlled by the first quadrant winds besides the characteristic thermal stratification processes at the summer period. The circulation patterns for the Ubatuba inner shelf region may result from interaction among the stress wind forces, the Coriolis force, pressure gradients and friction forces producing superficial and internal oscillations in the water column. Considering the wind field (Fig. 3A and B), the required time for equilibrium among the forces is at the same order of time between the observed oscillations from Feb. $19^{\text {th }}$ and Mar. $1^{\text {st }}$, approximately $200 \mathrm{~h}$. 

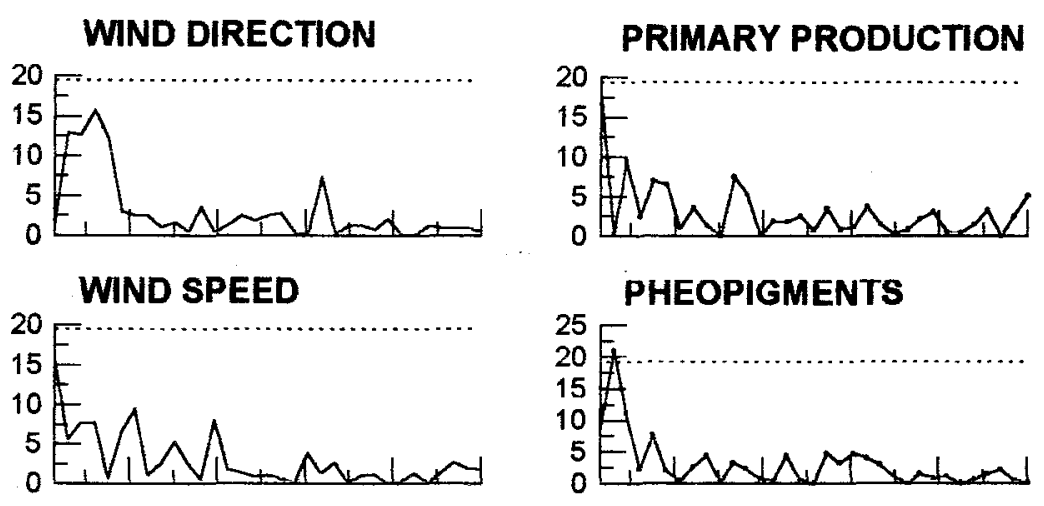

$\triangle$ TEMPERATURE

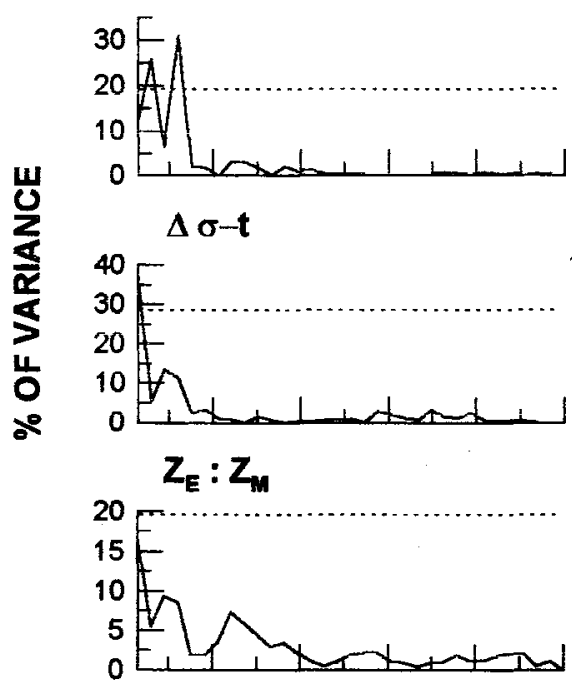

PHEO:CHLO

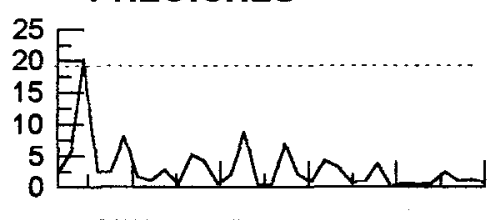

NITRATE
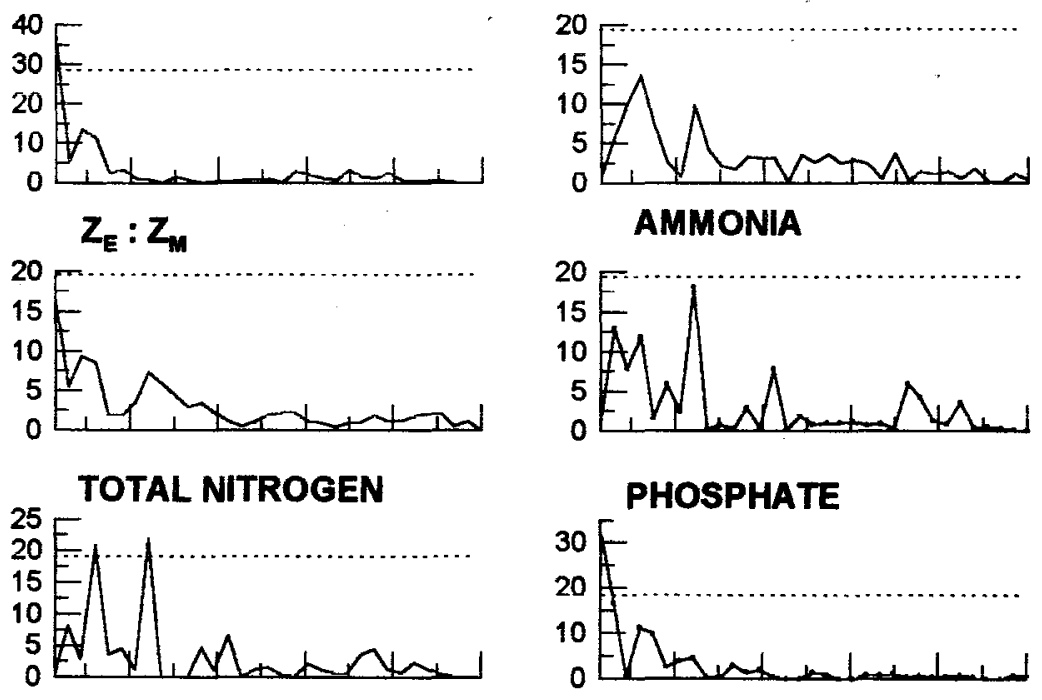

CHLOROPHYLL a
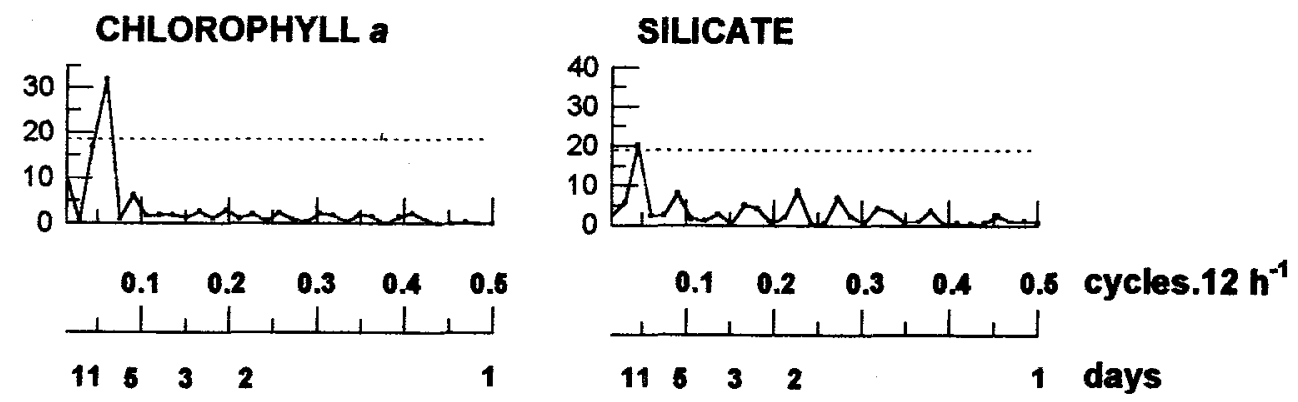

Fig. 5. Harmonic analysis: Periodograms.

The component II was interpreted as the transient frontal systems preceded by fourth quadrant winds (NW), and characterized by second and third quadrant winds, rain fall and turbulence periods resulting the increase of cloud covering with solar radiation reduction, addition of organic matter of continental origin to the water column and the increase of suspending matter with consequent higher turbidity. During the sampling period at summer, apparently, the coastal waters respond permanently to preceded wind stress episodes. Since the wind does not blow constantly, but rather is associated to atmospheric patterns that are typical of the weather conditions, it suggests its importance both to the physical processes and to the phytoplankton system. The forcing scale at the order 
of 200 hours strongly interacts with the phytoplankton doubling times and the growth rates, thus affecting the competition mechanisms and the diversity of the communities (Huston, 1979).

The third component (Fig. 4B) was interpreted as the phytoplankton responses to the turbulence and mixing processes caused by third and fourth quadrant winds which interrupt the normal first quadrant winds, typical of summer, as well as the nutrient inputs to the system due to heavy rain fall. Phytoplankton in this region during summer have been shown to be mainly dependent on regenerated sources of nitrogen (Metzler et al., $1995^{*}$ ), and in other coastal waters, regeneration of nitrogen has been shown to supply up to $100 \%$ of the nitrogen requirements for phytoplankton (Billen, 1978; Glibert, 1982; Harrison et al., 1983). In the inshore Ubatuba region, the mixed layer can also receive important $\mathrm{NO}_{3}^{-}$and $\mathrm{NH}_{4}^{+}$contributions by continental runoff and rain fall, mainly during summer (Braga, 1989; Susini-Zillmann, 1990). Shifts in the normal wind flow may also result in a release of nitrogen from the sediment to the euphotic zone. According to Mahiques (1992), detrital organic material from continental origin or from overlying waters deposits on the aerobic sediment and its decomposition results in an accumulation of $\mathrm{NH}_{4}{ }^{+}$as well as $\mathrm{NO}_{2}{ }^{-}$and $\mathrm{NO}_{3}{ }^{-}$close to the sediment surface.

Wind speed frequency distribution showed $39 \%$ of the observations from 0 to $2.0 \mathrm{~m} \mathrm{~s}^{-1}, 53 \%$ from 2.0 to $6.0 \mathrm{~m} \mathrm{~s}^{-1}$ and $8 \%$ from 6.0 to $12.0 \mathrm{~m} \mathrm{~s}^{-1}$. Parallel to these values, $74 \%$ of the wind direction observations were associated to the first quadrant, $18 \%$ to the second and third quadrants and $6 \%$ to the fourth quadrant. A comparison of the time series in Figs. $3 \mathrm{~A}$ and $\mathrm{B}$ shows that at most of the time the winds with intensities between 4.0 and $10.0 \mathrm{~m} \mathrm{~s}^{-1}$ were from the first quadrant, therefore, one can interpretate the fourth component as the forcing northeastern and eastern winds parallel to the coast, which drive the surface coast waters transport towards the ocean and the simultaneous colder and deeper waters normal transport towards the coast. In fact, water masses sampled, the Coast Water (CW) and the South Atlantic Central Water (SACW), confirm that their dynamics depend on the wind field, besides on the tide currents and on the bottom physiography as pointed by Castro Filho et al. (1987).

Observing the total inorganic nitrogen changes (Fig. 3H), one can see for period 1 (Feb. $12^{\text {th }}$

(*) Metzler, P. M.; Glibert, P. M.; Gaeta, S. A. \& Ludlam, J. 1995 New and regenerated production in the South Atlantic off Brazil. In: INTERNATIONAL SYMPOSIUM ON ENVIRONMENTAL BIOGEOCHEMISTRY, BIOSPHERE AND ATMOSPHERIC CHANGES, 12. Rio de Janeiro, 1995. Abstracts. Rio de Janeiro, Iseb. p. 54. to $23^{\text {th }}$ ) four peaks, for period 2 (Feb. $24^{\text {th }}$ to $29^{\text {th }}$ ) one peak, for period 3 (Mar $1^{\text {st }}$ to $\left.9^{\text {th }}\right)$ two peaks, and for period 4 (Mar $10^{\text {th }}$ to $15^{\text {th }}$ ) one peak. At period 1 , only the first peak (Feb. $17^{\text {th }}$ ) might be responding to the first quadrant winds pulse (Fig. 3A), and the second, third and fourth peaks (Feb. $18^{\text {th }}, 19^{\text {th }}$ and $23^{\text {rd }}$ ) might result from the increase of nitrogen associated to the intense rain fall observed at that time. At period 3, the second peak could be associated to turbulent mixing processes, judging the wind behavior. Thus, considering the four remaining peaks, one in each period (Feb. $17^{\text {th }}$ and $28^{\text {th }}$, Mar $4^{\text {th }}$ and $15^{\text {th }}$ ), a $200 \mathrm{~h}$ interval is obtained among the total nitrogen peaks. If now we compare these peaks with the values of wind direction referring to the first quadrant, the conclusion is a lag between the forcing first quadrant wind and the response of the total inorganic nitrogen in the order of 60 hours (Table 5). In the harmonic analysis (Fig. 5), it is seen that the total nitrogen peak at a 6.6 days period matches the largest peak of $\Delta T$; on the other hand, a second peak at a 4 days period matches the largest peak of ammonia. It is also noticeable from Table 5 that the first quadrant wind leads $\Delta \mathrm{T}$ by 36 hours and that $\Delta$ $\mathrm{T}$ is in phase with total nitrogen.

The phytoplankton biomass (Fig. 3J) showed one peak at period 1 (Feb. $18^{\text {th }}$ ), one peak at period 2 (Feb. $28^{\text {th }}$ ), two peaks at period 3 (Mar. $6^{\text {th }}$ and $7^{\text {th }}$ ) and one peak at period 4 (Mar. $15^{\text {th }}$ ). A comparison between these peaks with those from the total inorganic nitrogen suggests they were in phase (Table 5). The harmonic analysis of the phytoplankton biomass (Fig. 5) showed two indistinguishable peaks, one at a period of 8.25 days and one at a period of 6.6 days. The former is lagged about 3 days relative to the first peak of $\Delta T$ and about 5 days relative to the peak of $\Delta \sigma \mathrm{t}$, accounting for, respectively, 17 and $26 \%$ of variance. The latter is in phase with the first peak of the nitrogen.

In reference to the primary production (Fig. 3I), it is clear that the largest observed peak (Feb. $23^{\text {rd }}$ ) in all time series and the succession of oscillations between Mar. $5^{\text {th }}$ and $8^{\text {th }}$ were associated with the rain fall influence and with turbulent mixing processes, while the observed peaks at Mar $3^{\text {rd }}$ and $15^{\text {th }}$ were likely associated exclusively with the nutrient injection by a colder and richer water mass (Fig. 3D and 3E). From Table 5 it is seen that primary production is in phase with the euphotic:mixed layer ratio and is lagged about two days relative to wind field forcing normal to the coast $\left(0.302^{*}\right.$, a positive cross correlation); about 2.5 days relative to $\Delta \sigma_{t}$ and phytoplankton biomass; about 3 and 4 days relative to rain fall and $\Delta T$, respectively. A comparison between the peaks of 
Table 5. Cross correlations: Leading factors in the first column (abbreviations as in Table 1); lagged time between factors in brackets. $N=64$, number of lags $(k)=N / 4=16 ; k=12$ hours. Levels of significance: ${ }^{* *} p<0.01,{ }^{*}$ $\mathrm{p}<0.05$.

\begin{tabular}{|c|c|c|c|c|c|c|c|c|c|}
\hline & WDIR & WSPE & RAIN & $\Delta T$ & $\Delta \sigma \propto t$ & TOTN & CHLO & PPROD & ZEZM \\
\hline WDIR & - & - & $\begin{array}{l}0.349^{* *} \\
(24 \mathrm{hrs})\end{array}$ & $\begin{array}{l}-0.429^{* *} \\
(36 \mathrm{hrs})\end{array}$ & ns & $\begin{array}{l}-0.233^{*} \\
(60 \mathrm{hrs})\end{array}$ & ns & $\begin{array}{l}0.302^{*} \\
(48 \mathrm{hrs})\end{array}$ & ns \\
\hline WSPE & - & - & ns & $\begin{array}{l}0.461^{* *} \\
(96 \mathrm{hrs})\end{array}$ & $\begin{array}{l}-0.332^{* *} \\
(24 \mathrm{hrs})\end{array}$ & $\begin{array}{l}-0.285^{*} \\
(24 \mathrm{hrs})\end{array}$ & ns & ns & $\begin{array}{l}0.464^{* *} \\
(96 \mathrm{hrs})\end{array}$ \\
\hline RAIN & - & - & - & $\begin{array}{l}-0.350^{* *} \\
(36 \mathrm{hrs})\end{array}$ & $\begin{array}{l}0.378^{* *} \\
(12 \mathrm{hrs})\end{array}$ & $\begin{array}{l}-0.251^{*} \\
(48 \mathrm{hrs})\end{array}$ & $\begin{array}{l}-0.252^{*} \\
(36 \mathrm{hrs})\end{array}$ & $\begin{array}{l}0.522^{* *} \\
(72 \mathrm{hrs})\end{array}$ & ns \\
\hline$\Delta \mathrm{T}$ & - & - & - & - & - & $\begin{array}{l}0.356^{* *} \\
(0 \mathrm{hrs})\end{array}$ & $\begin{array}{l}0.381^{* *} \\
(0 \mathrm{hrs})\end{array}$ & $\begin{array}{l}0.251^{*} \\
(96 \mathrm{hrs})\end{array}$ & $\begin{array}{l}0.730^{* *} \\
(0 \mathrm{hrs})\end{array}$ \\
\hline$\Delta \sigma-t$ & - & - & - & - & - & $\begin{array}{l}-0.228^{*} \\
(108 \mathrm{hrs})\end{array}$ & $\begin{array}{l}-0.369^{* *} \\
\text { (96 hrs) }\end{array}$ & $\begin{array}{l}0.476^{* *} \\
(60 \mathrm{hrs})\end{array}$ & ns \\
\hline TOTN & - & - & - & - & - & - & $\begin{array}{l}0.335^{* *} \\
(0 \mathrm{hrs})\end{array}$ & $\begin{array}{l}0.335^{* *} \\
(108 \mathrm{hrs})\end{array}$ & - \\
\hline CHLO & - & - & - & - & - & - & - & $\begin{array}{l}0.435^{* *} \\
(60 \mathrm{hrs})\end{array}$ & - \\
\hline PPROD & - & - & - & - & - & - & - & - & - \\
\hline ZEZM & - & - & - & - & - & $\begin{array}{l}0.403^{* *} \\
(0 \mathrm{hrs})\end{array}$ & $\begin{array}{l}0.354^{* *} \\
(0 \mathrm{hrs})\end{array}$ & $\begin{array}{l}0.276^{*} \\
(0 \mathrm{hrs})\end{array}$ & - \\
\hline
\end{tabular}

primary production and total inorganic nitrogen (Figs 3I and 3H) suggests a lag about 108 hours (Table 5).

One nonsignificant peak revealed in the harmonic analysis of primary production, accounting for $18 \%$ of variance at a period of 15 days, matches the peaks of $\Delta \sigma_{t}$ and ZE:ZM (Fig. 5). Phytoplankton biomass and primary production are lagged about 60 hours (Table 5). Therefore, photosynthetic characteristics indicate a response to the leading factor total nitrogen from four to five days, while the response of phytoplankton biomass is practically in phase.

In our time series in Ubatuba region, the atmospheric forcing showed a characteristic period of about 200-264 hours and the phytoplankton biomass response ranged over the 144-192 hours time scales. The photosynthetic characteristics of the phytoplankton were best related to the environment 360 hours before, although their oscillations throughout the time series were lagged about 96-144 hours relative to nitrogen and biomass. Primary production responses (Fig. 3I) seem to follow roughly the ZE:ZM changes (Fig. 3G) at a scale of days. Since the period between transient frontal events is approximately equivalent to the photosynthetic response time of the phytoplankton (sensu Harris, 1986), one could suppose this system as in nonsteady state. At these conditions, the reserve compounds of the metabolical routes become very important and the phytoplankton cells can be seen as integrators trying to buffer their internal biosynthetic pathways from external fluctuations, at the same time they grow at rates as close as possible to the maximum (Morris, 1980; Eppley, 1981). With a fast uptake and storage of nutrients, the phytoplankton may require nutrients only for brief periods during growth (McCarthy \& Goldman, 1978). The populations can continue growing rapidly as long as they are supplied with nitrogen and phosphorus at least once a week (Eppley, op. cit.). This may be the case in the Ubatuba region as seen from Figure 5, in which the total nitrogen peaks at a 6.6 days period matching the largest peak of $\Delta T$, and peaks at a 4 days period matching the largest peak of ammonia.

The 8-11 days atmospheric disturbances suggest to be major constraints regulating dynamics of the Ubatuba coastal phytoplankton assemblages. Day-to-day variations of phytoplankton standingstock (Francos, 1996) studied at the same time series presented in this paper, showed the algal community composed by nanoflagellates and small pennate diatoms with transient appearances of dinoflagellates (Fig. 6). According to these studies, storms can play an important role in determining the phasic nature of the summer succession. At surface (Fig. 6 top) nanoflagellates peaks characterize the "after-storm" (see Fig. 3C) group of small algae, whereas at 50 and $1 \%$ light depths near $5-10 \%$ of the standingstock is composed by diatoms. Calm periods

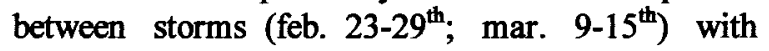




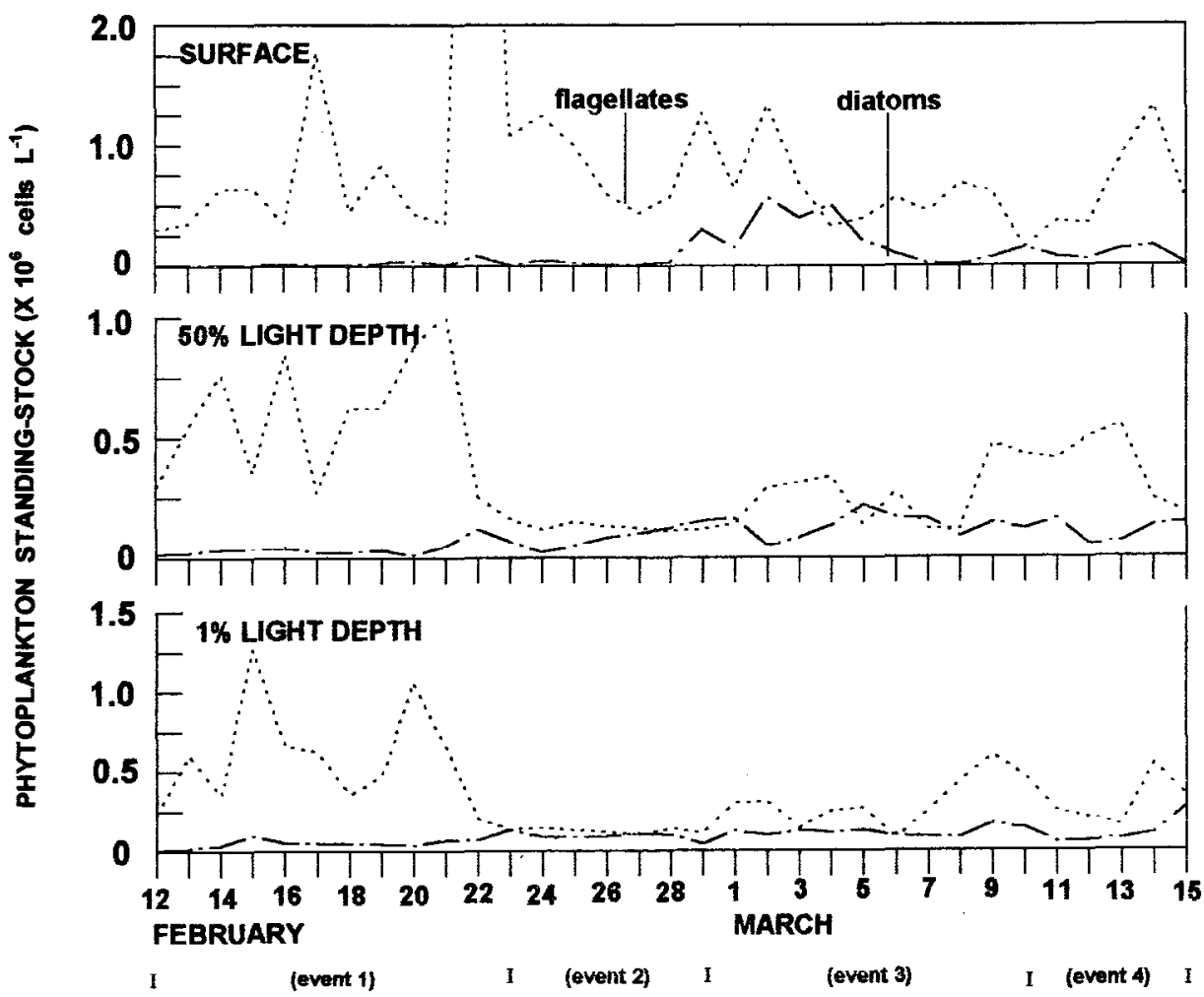

Fig. 6. Day-to-day variations in the most abundant taxonomic groups of the phytoplankton at the sampling station (from Francos, 1996).

increasing stratification (see Fig. 3D) characterize the "pre-storm" wide dominance of nanoflagellates only at surface whereas at 50 and $1 \%$ light depths diatoms account for $25-50 \%$ of the standing-stock. Mixing caused by atmospheric disturbances has a beneficial effect on diatoms which indeed surpass nanoflagellates at surface. This relationship is assumed to be related to the dominant hydrodynamic vertical difusive processes that enhance water nutrient concentrations (see Fig. 3H). A surface bloom composed mainly by Pseudo-nitzschia sp and Dactyliosolen fragilissimus from $1^{\text {st }}$ to $5^{\text {th }}$ march (Fig. 6 top) reinforces the relationship stated above (Francos, 1996).

In a 5-day time series conducted in the same Ubatuba region, Metzler et al. (1995) observed an upwelling event, during which the $\mathrm{NO}_{3}^{-}$ concentrations at the base of the euphotic zone increased over 10 -fold. While primary production was observed to increase in relation to increases in $\mathrm{NO}_{3}^{-}$, this increase was considerably smaller, $\sim 2-$ fold. No coincident increase was observed in chlorophyll $a$. A longer time series would have been required to determine whether such an increase eventually followed and the time scale of the lag relative to the $\mathrm{NO}_{3}{ }^{-}$upwelling.

It should be pointed out that our results derived from multivariate and harmonic analysis would not necessarily hold to other neighbouring regions or time periods. The relevant point is that they indicate a variability in the coupling between both physicochemical and biological fields, which, is impelled around by, and probably at the most of time generated by, a locally shared pattern of environmental forcing.

Ongoing work off the Southeastern Brazil Bight, between the coastal cities of Ubatuba and Iguape, shows both in austral summer and winter a Brazil Current cyclonic meandering pattern while, at the same time, is verifying a possible correlation between this pattern and shelf break upwelling of deeper water (SACW) onto the outer continental shelf (Silva, 1994). Warm and cold-core meanders are important mechanisms for exchange of slope water across western boundary current systems, and have been shown to transport nutrients onto the continental shelf of the São Paulo State (Gaeta et al., 1994*). In this area, during summer 1993, nitrate concentrations in the euphotic zone over the shelf showed a gradual increasing trend in an inshore direction, ranging from 0.5-7.0 $\mu \mathrm{M}$, and upwelled nitrate $(1.5-2.0 \mu \mathrm{M})$ was observed in the

(*) Gaeta, S. A.; Brino, O. L. \& Susini Ribeiro, S. M. M. 1994 Distributions of nitrate, chlorophyll $a$, and primary productivity in the Southwestern Region of the South Atlantic During Summer. In: SOUTHWESTERN ATLANTIC PHYSICAL OCEANOGRAPHY WORKSHOP. São Paulo, 1994. Abstracts. São Paulo, Labmon/IOUSP. p. 57-60. 
inner shelf and in the slope. Below the euphotic zone, nitrate values also increased gradually towards the shelf, following crudely the isobaths downstream (south) of the curving portions which diverge for several tens of kilometers. Another mechanism postulates surface variations in the mesoscale distribution of chemical and biological properties by the horizontal advection of a cold water mass originating at Cabo Frio due to a strong upwelling event (Lorenzzetti \& Gaeta, 1996).

\section{Conclusions}

Our results show that wind field forcing parallel to the coast drives the stratification settlement through which SACW forcing increases nutrient availability; calm periods between storms characterize the "pre-storm" wide dominance of nanoflagellates only at surface whereas at 50 and $1 \%$ light depths, diatoms account for up to $50 \%$ of the phytoplankton standing-stock; averaged primary production values are about $0.5 \mathrm{gC} \mathrm{m}^{-2}$ day $^{-1}$. Wind field forcing normal to the coast determines mixing which has a beneficial effect on diatoms that dominate the water column. Rain forcing, on the other hand, leads to the "after-storm" phytoplankton assemblages at surface, characterized by small algae whereas at 50 and $1 \%$ light depths near $5-10 \%$ of the standing-stock is composed by diatoms, and, at the same time, increases nutrient contributions by continental runoff; as a result, primary production increases over 2-fold.

Two indistinguishable significant peaks have been observed in the harmonic analysis of the phytoplankton biomass of Ubatuba coastal waters: one at a period of 8.25 days and one at a period of 6.6 days. These contribute, respectively, about 17 and $32 \%$ of the total variance of phytoplankton biomass. Total dissolved nitrogen concentrations account for most of these variations.

Two distinct significant peaks have been observed in the periodogram of the total dissolved nitrogen: one at a period of 6.6 days and one at 4 days, contributing, respectively, about 21 and $22 \%$ of the total variance. At the period of 6.6 days total nitrogen peak matches the stability parameter $\Delta \mathrm{T}$ and at a period of 4 days matches the ammonia concentration peak.

Changes in water column stability at periods of 11-15 days suggest that it is controlled by wind field. Although wind events are known to be important sources of phytoplankton biomass changes, this study revealed that the regular periodic wind field forcing is, at least during summer, a major influence.
One non significant peak has been observed in the harmonic analysis of primary production accounting for by $18 \%$ of variance at a period of 15 days, thus being partially related to the water column stability and partially to the ratio euphotic zone:mixing depth.

In Ubatuba region, the atmospheric forcing showed a characteristic period of about 200-264 hours and the phytoplankton biomass response ranged over the 144-192 hours time scales. The photosynthetic characteristics of the phytoplankton were best related to the environment 360 hours before, although their oscillations were lagged about 96-144 relative to nitrogen and biomass.

During summer, the interruption of steadystate conditions by transient atmospheric events and wind field intensification are the determining factors driving phytoplankton changes in this coastal environment.

\section{Acknowledgements}

The first author acknowledges the Fellowship Grants no. 520352/95-5 support from the Conselho Nacional de Desenvolvimento Científico e Tecnológico (CNPq). S. M. Susini Ribeiro acknowledges the Post-Doctoral Scholarship no. 97/13905-7 from Fundação de Amparo à Pesquisa do Estado de São Paulo (FAPESP); M. S. Francos acknowledges the Scholarship Grant No 91/1589-7 (FAPESP). We thank Dr. Patricia M. Glibert for valuable comments on an earlier version of the manuscript and two anonymous referees for constructive criticism of the manuscript.

\section{References}

Aminot, A. \& Chaussepied, M. 1983. Manuel des analyses chimiques en millieu marin. Brest, CNEXO. 395 p.

Anderson, T. W. 1971. The statistical analysis of time series. New York, John Wiley. 704p.

Billen, G. 1978. A budget of nitrogen recycling in North Sea sediments off the Belgian coast. Estuar. coast. mar. Sci., 7(2):127-146.

Boyce, F. M. 1974. Some aspects of Great Lakes physics of importance to biological and chemical processes. J. Fish. Res. Bd Can., 31(5):689-730. 
Braga, E. S. 1989. Estudo dos nutrientes dissolvidos nas águas da Enseada das Palmas, ilha Anchieta (Ubatuba, SP), com ênfase às formas nitrogenadas e contribuição por aportes terrestres e atmosféricos. Dissertação de mestrado. Universidade de São Paulo, Instituto Oceanográfico. $207 \mathrm{p}$.

Castro Filho, B. M.; Miranda, L. B. de \& Miyao, S. Y. 1987. Condições hidrográficas na plataforma continental ao largo de Ubatuba: variações sazonais e em média escala. Bolm Inst. oceanogr., S Paulo, 35(2):135-151.

Denman, K. L. \& Gargett, A. E. 1983. Time and space scales of vertical mixing and advection of phytoplankton in the upper ocean. Limnol. Oceanogr., 28(5):801-815.

Draper, N. R. \& Smith, H. 1966. Applied regression analysis. New York, John Wiley. p. 171.

Eppley, R. W. 1981. Relations between nutrient assimilation and growth in phytoplankton with a brief review of estimates of growth rate in the ocean. Can. Bull. Fish. aquat. Sci., 210:251263.

Francos, M. S. 1996. Variações diárias sazonais (verão e inverno) do "standing-stock" do fitoplâncton e da biomassa em termos de clorofila $a$ em duas estações fixas costeiras na

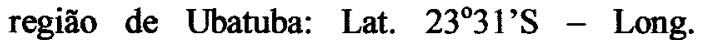
$45^{\circ} 05^{\prime} \mathrm{W}$ e Lat. $23^{\circ} 51^{\prime} \mathrm{S}$ - Long. $44^{\circ} 56^{\prime} \mathrm{W}$. Dissertação de mestrado. Universidade de São Paulo, Instituto Oceanográfico. 123p.

Gaeta, S. A.; Abe, D. S.; Susini, S. M.; Lopes, R. M. \& Metzler, P. M. 1990. Produtividade primária, plâncton e covariáveis ambientais no Canal de São Sebastião durante o outono. Rev. Brasil. Biol., 50(4):963-974.

Glibert, P. M. 1982. Regional studies of daily, seasonal and size fraction variability in ammonium remineralization. Mar. Biol. 70:209-222.

Grasshoff, K.; Ehrhardt, M. \& Kremling, K. 1983. Methods of seawater analysis. $2^{\text {nd }}$ ed. New York, Verlag Chemie. 419 p.

Harris, G. P. 1980. Temporal and spatial scales in phytoplankton ecology. mechanisms, methods, models, and management. Can. J. Fish. aquat. Sci., 37(5):877-900.
Harris, G. P. 1986. Phytoplankton ecology: structure, function and fluctuation. $1^{\text {st }}$ ed. New York, Chapman and Hall. 384 p.

Harrison, W. G.; Douglas, D.; Falkowski, P.; Rowe, G. \& Vidal, J. 1983. Summer nutrient dynamics of the Middle Atlantic Bight: nitrogen uptake and regeneration. J. Plankt. Res. 5(4):539-556.

Huston, M. 1979. A general hypothesis of species diversity. Am. Nat., 113(1):81-101.

Jeffrey, A. D. \& Humphrey, G. F. 1975. New spectrophotometric equations for determining chlorophylls a, b, c1 and c2 in higher plants, algae, and natural phytoplankton. Biochem. Physiol. Pfl., 167:191-194.

Jenkins, G. M. \& Watts, L. G. 1968. Spectral analysis and its applications. San Francisco, Holden-Day. 525p.

Kutner, M. B. B. 1961. Algumas diatomáceas encontradas sobre algas superiores. Bolm Inst. oceanogr., S Paulo, 11(3):3-11.

Kutner, M. B. B. \& Sassi, R. 1979. Dinoflagellates from the Ubatuba region (Lat. 23\%30'S-Long. $4^{\circ} 06^{\prime}$ W) Brazil. In: Taylor, D. L. \& Seliger, H. eds Toxic dinoflagellates blooms. New York, Elsevier. p. 169-172.

Legendre, L. \& Legendre, P. 1984a. Écologie numérique. 1. Le traitement multiple des données écologiques. $2^{\circ}$ éd. Québec, Masson Presses de l'Université du Québec. 260p.

Legendre, L. \& Legendre, P. 1984b. Écologie numérique. 2. La structure des données écologiques. $2^{\mathrm{e}}$ éd. Québec, Masson Presses de l'Université du Québec. 335p.

Lorenzen, C. J. \& Jeffrey, S. W. 1980. Determination of chlorophyll in seawater. UNESCO tech. Pap. mar. Sci., 35:1-20.

Lorenzzetti, J. A. \& Gaeta, S. A. 1996. The Cape Frio Upwelling effect over the South Brazil Bight northern sector shelf waters: a study using AVHRR images. Int. Arch. Photogramm., 31(7):448-453.

Mahiques, M. M. 1992. Variações temporais na sedimentação quaternária dos embaiamentos da região de Ubatuba, Estado de São Paulo. Tese de doutorado. Universidade de São Paulo, Instituto Oceanográfico. $2 v$. 
Margalef, R. 1978. Life-forms of phytoplankton as survival alternatives in an unstable environment. Oceanol. Acta, 1(4):493-509.

McCarthy, J. J. \& Goldman, J. C. 1979. Nitrogenous nutrition of marine phytoplankton in nutrientdepleted waters. Science, 203:670-672.

Millard, R. C.; Owens, W. B. \& Fofonoff, N. P. 1990. On the calculation of the Brunt-Väisäla frequency. Deep-Sea Res., 37(1A):167-181.

Morris, I. 1980. Paths of carbon assimilation in marine phytoplankton. In: Falkowski, P. ed. Primary productivity in the sea. New York, Plenum Press. p. 139-160.

Oliveira, I. R. 1980. Distribuição das diatomáceas epifiticas na região de Ubatuba. Dissertação de mestrado. Universidade de São Paulo, Instituto Oceanográfico. 88p.

Perazza, M. C. D. 1982. Variação sazonal do fitoplâncton e fatores ambientais na Enseada do Flamengo (Lat. $23^{\circ} 30^{\prime}$ S-Long. $45^{\circ} 06^{\prime} \mathrm{W}$ ): algumas considerações metodológicas. Dissertação de mestrado. Universidade de São Paulo, Instituto Oceanográfico. 105p.

Platt, T. \& Denman, K. L. 1975. Spectral analysis in ecology. A. Rev. Ecol. Syst., 6:189-210.

Sassi, R. 1978. Variação sazonal do fitoplâncton e fatores ecológicos básicos da região do Saco da Ribeira (Lat. $23^{\circ} 30^{\prime} \mathrm{S}-$ Long. $45^{\circ} 07^{\prime} \mathrm{W}$ ), Ubatuba, Brasil. Dissertação de mestrado. Universidade de São Paulo, Instituto Oceanográfico. 147p.

Sassi, R. \& Kutner, M. B. B. 1982. Variação sazonal do fitoplâncton da região do Saco da Ribeira (Lat. 2330'S; Long. $45^{\circ} 07^{\prime} \mathrm{W}$ ). Ubatuba, Brasil. Bolm Inst. oceanogr., S Paulo, 31(2):29-42.

Silva, M. P. 1994. Caracterização físico-química das massas de água da Bacia de Santos durante o Projeto COROAS. Verão e inverno de 1993. Dissertação de mestrado. Universidade de São Paulo, Instituto Oceanográfico. 135p.

Smayda, T. J. 1970. The suspension and sinking of phytoplankton in the sea. Oceanogr. mar. Bio. a. Rev., 8:353-414.
Soares, F. S. 1983. Estudo do fitoplâncton de águas costeiras e oceânicas da região de Cabo Frio-RJ $\left(23^{\circ} 31^{\prime} \mathrm{S}-41^{\circ} 52^{\prime} \mathrm{W}\right)$ até o Cabo de Santa Marta Grande-SC $\left(28^{\circ} 43^{\prime} S-47^{\circ} 57^{\prime} \mathrm{W}\right)$. Dissertação de mestrado. Universidade de São Paulo, Instituto Oceanográfico. 118p.

Susini-Zillmann, S. M. 1990. Distribuição sazonal do fitoplâncton na radial entre ilha Anchieta e ilha da Vitória (Lat. $23^{\circ} 31^{\prime}$ S-Long. $45^{\circ} 06^{\prime} \mathrm{W}$ à Lat. $23^{\circ} 45^{\prime}$ S-Long. $45^{\circ} 01^{\prime} \mathrm{W}$ ) da região de Ubatuba, São Paulo. Dissertação de mestrado. Universidade de São Paulo, Instituto Oceanográfico. 2v.

Teixeira, C. 1973. Preliminary studies of primary production in the Ubatuba region (Lat. 23\%30'SLong. $45^{\circ} 06^{\prime} \mathrm{W}$ ), Brazil. Bolm Inst. oceanogr., S Paulo, 22:49-58.

Teixeira, C. 1979. Produção primária e algumas considerações ecológicas da região de Ubatuba (Lat. $23^{\circ} 30^{\prime}$ S-Long. $45^{\circ} 06^{\prime} \mathrm{W}$ ), Brasil. Bolm Inst. oceanogr., S Paulo, 28(2):23-28.

Teixeira, C. 1980. Estudo quantitativo da produção primária, clorofila $a$ e parâmetros abióticos em relação à variação temporal (Lat. 23⒊'S-Long. $45^{\circ} 06^{\prime} \mathrm{W}$ ). Tese de livre-docência. Universidade de São Paulo, Instituto Oceanográfico. 243p.

Teixeira, C. \& Tundisi, J. G. 1981. The effects of nitrogen and phosphorus enrichments on phytoplankton in the region of Ubatuba (Lat. $23^{\circ} 30^{\prime}$ S-Long. $45^{\circ} 06^{\prime} \mathrm{W}$ ), Brazil. Bolm Inst. oceanogr., S Paulo, 30(1):77-86.

Teixeira, C. 1986. Daily variation of marine primary production in the Flamengo Inlet, Ubatuba region, southern Brazil. In: Bicudo, C. E. M.; Teixeira, C. \& Tundisi, J. G. eds Algas: a energia do amanhã. Universidade de São Paulo, Instituto Oceanográfico. p. 97-108.

Teixeira, C. \& Gaeta, S. A. 1990 . Contribution of picoplankton to primary production in estuarine, coastal and equatorial waters of Brazil. Hydrobiologia, 209(2):117-122.

Tundisi, J. G.; Teixeira, C.; Matsumura-Tundisi, T.; Kutner, M. B. B. \& Kinoschita, L. 1978. Plankton studies in a mangrove environment. IX. Comparative investigations with a coastal oligotrophic waters. Rev. Brasil. Biol., 38(2):301-320. 
Turpin, D. H. \& Harrison, P. J. 1979. Limiting nutrient patchiness and its role in phytoplankton ecology. J. exp. mar. Biol. Ecol., 39:151-166.

UNESCO 1981a. Background papers and supporting data on the Practical Salinity Scale. 1978. UNESCO tech. Pap. mar. Sci., 37:1-144.
UNESCO 1981b. Background papers and supporting data on the International Equation of State of Seawater 1980. UNESCO tech. Pap. mar. Sci., 38:1-192.

(Manuscript received 09 October 1998; revised 03 March 1999; accepted 10 March 1999) 